\title{
PEMBELAJARAN ANGKLUNG UNTUK SLB BAGIAN B TUNA RUNGU MENGGUNAKAN COLOURING SCORE BERBASIS MULTIMEDIA
}

\author{
Diana Effendi*1, Bella Hardiyana ${ }^{2}$ \\ ${ }^{1}$ Program Studi Manajemen Informatika, Fakultas Teknik dan Ilmu Komputer, Universitas \\ Komputer Indonesia \\ ${ }^{2}$ Program Studi Sistem Informasi, Fakultas Teknik dan Ilmu Komputer, Universitas Komputer \\ Indonesia \\ *E-mail: diana.effendi@email.unikom.ac.id
}

\begin{abstract}
This paper is the result of the activity of the Program Kemitraan Masyarakat (PKM) funded by the Direktorat Riset dan Pengabdian Kepada Masyarakat Direktorat Jenderal Penguatan Riset dan Pengembangan Kementrian Pendidikan dan Kebudayaan in accordance with Contract Number: 108 / SP2H / PPM / DPRM / 2019, March 082019 with SLB Negeri Cicendo as PKM activity partners. The resulting product is a multimedia-based angklung learning application program for the deaf desktop and mobile versions. The desktop version application is used when practising together. Students play angklung by looking at the direction of the application displayed through the screen. Students move angklung based on the colour that will appear on the monitor called a colour score. While the mobile version of the multimedia application is used when students learn angklung at home independently, they simply move the mobile device as a substitute for angklung. Procedures in the making application programs are determining the concept, Media Design, Material Collection Development Process, and Testing. The results of this PKM activity are students are more focused when to move angklung by paying attention to the colour change (colouring score)
\end{abstract}

Keywords—angklung, the deaf, colouring score method, multimedia

\begin{abstract}
Abstrak
Tulisan ini merupakan hasil dari kegiatan Program Kemitraan Masyarakat (PKM) didanai Direktorat Riset dan Pengabdian Kepada Masyarakat Direktorat Jenderal PenguatanRiset dan Pengembangan Kementrian Pendidikan danKebudayaan sesuai dengan Kontrak Nomor :108/SP2H/PPM/DPRM/2019, tanggal 08 Maret 2019 dengan SLB Negeri Cicendo sebagai mitra kegiatan PKM. Produk yang dihasilkan berupa program aplikasi pembelajaran angklung untuk tunarungu berbasis multimedia berbasis desktop dan mobile. Aplikasi versi desktop digunakan pada saaat berlatih bersama. Peserta didik memainkan angklung dengan melihat arahan dari aplikasi yang ditampilkan melalui layar. Peserta didik menggerakkan angklung berdasarkan warna yang akan tampil di monitor yang disebut dengan colouring score. Sedangkan aplikasi multimedia versi mobile digunakan ketika peserta didik belajar angklung di rumah secara mandiri, dengan hanya menggerakkan perangkat mobile sebagai pengganti dari angklung. Prosedur dalam pembuatan program aplikasi yaitu menentukan konsep, Desain Media, Pengumpulan Bahan Proses Pembuatan, dan Uji Coba. Hasil dari kegiatan PKM ini yaitu siswa lebih fokus kapan harus menggerakkan angklung dengan memperhatikan perubahan warna (colouring score).
\end{abstract}

Kata kunci-angklung, tunarungu, metode colouring score, multimedia

\section{PENDAHULUAN}

$\mathrm{P}_{\mathrm{p}}$ enyandang disabilitas termasuk peserta didik tunarungu memiliki hak yang sama dalam bidang pendidikan seperti layaknya peserta didik lainnya yang normal secara fisik. Hal ini jelas 
dinyatakan dalam Undang-Undang Republik Indonesia nomor 8 tahun 2016 tentang penyandang Disabilitas pada bagian keenam mengenai hak pendidikan pasal keenam ayat 1. Dimana dalam pasal ini menyatakan bahwa penyandang disabilitas memiliki hak mendapatkan pendidikan yang bermutu pada satuan pendidikan di semua jenis, jalur dan jenjang pendidikan secara inklusif dan khusus [1]. Artinya hal ini juga berlaku bagi peserta didik tunarungu, memiliki hak yang sama dalam mempelajari musik angklung. Seperti diketahui musik angklung saat ini sudah menjadi salah satu pelajaran dalam kurikulum yang ada di sekolah sebagai mata pelajaran muatan lokal daerah.

Angklung pada umumnya dikenal di wilayah Jawa Barat yang merupakan lokasi asalnya. Sejak bulan November tahun 2010, UNESCO mencatat alat musik itu sebagai salah satu dari sekian banyak warisan kebudayaan di dunia, dengan golongan dan diakui berkategori Masterpiece of Oral and Intangible Heritage of Humanity kala itu [2,3,4]. Angklung merupakan alat musik yang terbuat dari beberapa pipa bambu dengan berbagai ukuran yang dilekatkan pada sebuah bingkai bambu.

Cara memainkan alat musik angklung adalah satu tangan memegang bagian atas angklung dan tangan lain memegang bagian bawah dari sisi lain angklung tersebut lalu menggoyangkannya. Setiap satu alat musik angklung hanya menghasilkan satu nada. Oleh karena itu, dibutuhkan beberapa pemain angklung untuk menghasilkan melodi yang indah untuk didengar [5]. Seorang pemain angklung dapat memainkan 2 atau 3 buah alat musik angklung. Dengan kata lain cara bermain angklung dilakukan secara ansambel. Ansambel musik merupakan sebuah sajian musik yang dilakukan secara bersama-sama dengan menggunakan satu jenis atau berbagai jenis alat musik[6].

SLB Negeri Cicendo yang merupakan mitra dalam kegiatan Program Kemitraan Masyarakat (PKM) ini juga menyelenggarakan pembelajaran angklung sebagai kegiatan ekstrakurikuler yang diikuti oleh peserta didik dari jenjang SD, SMP dan SMA dengan peserta sampai dengan saat ini kurang lebih 30 orang peserta didik. Tentu metode cara pembelajaran angklung untuk peserta didik tunarungu sangatlah berbeda dengan peserta didik normal. Seperti diketahui tunarungu mempunyai keterbatasan dalam pendengaran. Gangguan pendengaran tunarungu meliputi tingkatan ringan, sedang, berat dan sangat berat yang diakibatkan oleh organ pendengaran yang tidak berfungsi secara maksimal [7,8]. Pembelajaran angklung di SLB Negeri Cicendo dilakukan dengan menggabungkan Metode Demonstrasi dan Metode Maternal Reflektif (MMR) [9]. Metode Maternal Reflektif (MMR) merupakan metode pembelajaran bahasa yang pertama kali diperkenalkan oleh A. van Uden yang didasarkan pada cara seorang ibu mengajarkan bahasa pada anaknya melalui percakapan yang penuh kasih sayang, alamiah, spontan, serta menggunakan bahasa sehari-hari $[9,10]$. Metode pengajaran tunarungu mengutamakan visual, dimana dalam pengajaran angklung guru mempraktekan secara langsung bagaimana memegang angklung, memainkan angklung dengan menggunakan bahasa isyarat. Tujuan dimainkannya alat musik angklung oleh para siswa tunarungu ini adalah untuk meningkatkan konsentrasi dari para pemain [11]. Pemain dituntut untuk selalu memperhatikan pelatihnya untuk menentukan waktu menggetarkan angklung.

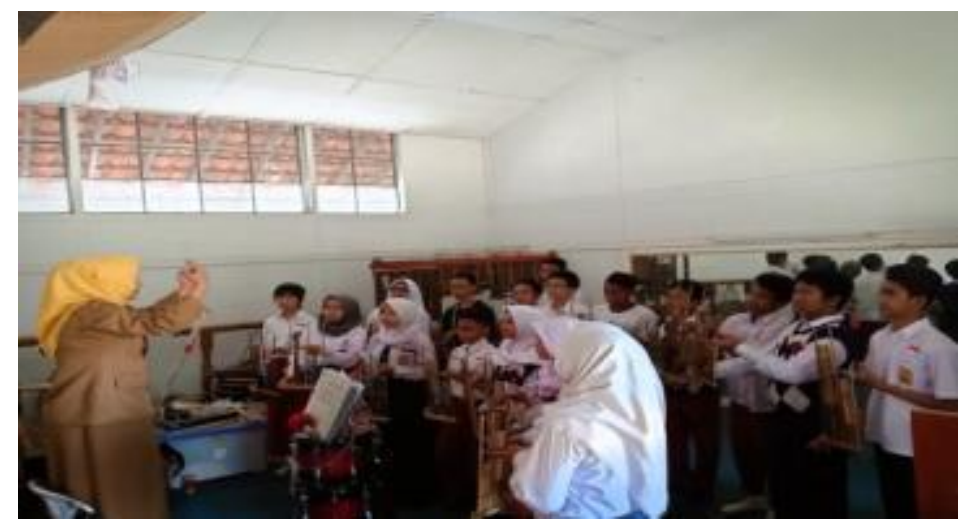

Gambar 1 Pengajaran Angklung Di SLB N Cicendo

Terdapat kendala dalam pembelajaran angklung di mitra saat ini antara lain kurangnya simbol tangan yang mewakili notasi tertentu masih terbatas pada nada utama. Sehingga para peserta tidak dapat memainkan lagu yang didalamnya terdapat nada naik atau turun setengah karena belum 
terwakili oleh simbol tangan. Untuk menghasilkan nada yang harmonis antara melodi dan akor harus dilakukan oleh dua orang guru. Keterbatasan waktu dalam pelaksanaan pembelajaran angklung juga membuat pembelajaran angklung tidak terlaksana dengan baik. Kurangnya pengetahuan guru pada suatu instrumen musik dapat mempengaruhi keterampilan siswa dalam memainkan alat musik, khususnya angklung. Siswa hanya mengenal angklung sebagai media bermain yang mengeluarkan bunyi yang unik, sehingga saat diberi aba-aba untuk bermain musik menggunakan angklung siswa cenderung tidak fokus [9].

Untuk mengatasi permasalahan tersebut dalam kegiatan PKM ini dibuatlah suatu program aplikasi pembelajaran angklung berbasis multimedia. Multimedia berasal dari dua kata, yaitu multi dan media. Multi berarti banyak dan media biasa diartikan alat untuk menyampaikan atau membuat sesuatu, perantaraan, alat pengantar, suatu bentuk komunikasi [12]. Program aplikasi ini dibuat dalam dua versi yaitu desktop dan berbasis mobile.

Untuk program aplikasi berbasis desktop peserta didik memainkan angklung dengan melihat arahan dari aplikasi yang ditampilkan melalui layar dengan menggerakkan angklung berdasarkan warna yang akan tampil di monitor yang disebut dengan colouring score(pewarnaanpartitur). Sedangkan aplikasi multimedia versi mobile digunakan ketika peserta didik belajar angklung di rumah secara mandiri. Dengan dibuatkannya aplikasi multimedia interaktif tersebut, peserta didik dapat mempelajari angklung dengan mempelajari materi pengenalan angklung yang animatif, latihan memainkan lagu dengan menggunakan metode colouring score.

\section{METODE}

Tahapan pertama dalam kegiatan dalam Program Kemitraan Masyarakat ini yaitu membangun program aplikasi pembelajaran angklung berbasis multimedia berbasis desktop dan android. Tahap selanjutnya adalah melatih siswa agar mahir menggunakan program aplikasi pembelajran angklung tersebut.

Dalam pembangunan program aplikasi pembelajaran angklung tersebut terdapat lima tahapan dalam pembuatan program aplikasi pembelajaran angklung ini yakni: (1) menentukan konsep (concept), (2) Desain Media (Design), (3) Pengumpulan Bahan (Material Collecting), (4) Proses Pembuatan (Assembly), dan (5) Uji Coba (Testing).

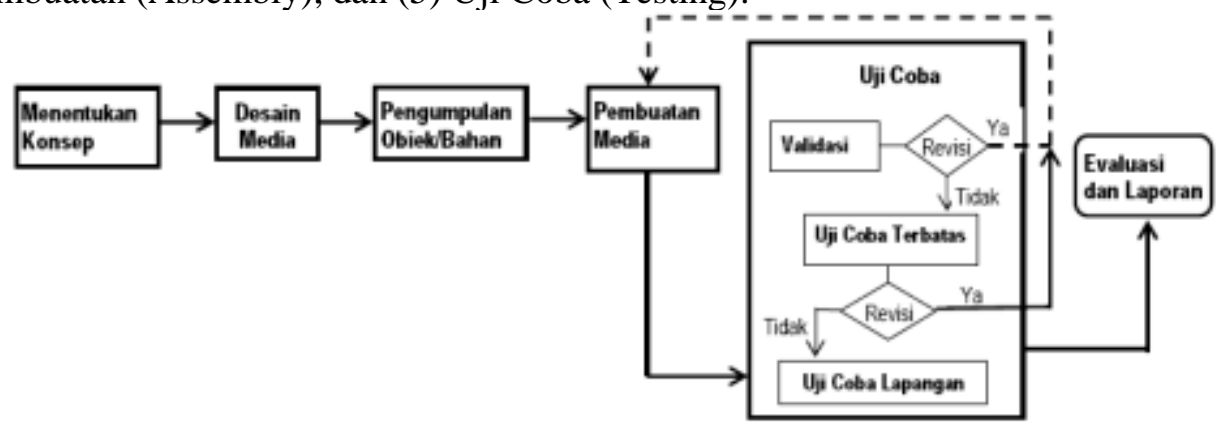

\section{Gambar 2 Prosedur Pelaksanaan PKM}

1. Tahap menentukan konsep merupakan tahapan dalam menentukan media animasi yang akan dibuat berdasarkan hasil analisis tentang silabus yang dikembangkan di objek penelitian.

2. Tahap desain bertujuan untuk membuat spesifikasi secara rinci mengenai arsitektur media, alur interaksi, gayadan kebutuhan material untuk produk media.

3. Tahap pengumpulan bahan dilakukan berdasarkan konsep dandesain mencakup : materi pelajaran, gambar, foto, animasi, foto yang telah diedit, musik pengiring danpengumpulan suara (sound effect). Proses pembuatanmedia animasi dilakukan mengacupada story board (alurcerita/ deskripsi struktur program komputer), flowchart (diagram alir ) dan struktur navigasi berasal dari tahap design. Uji coba dilakukan dalam dua tahap yaitu validasi dengan pelatih angklung dan peserta didik. 
Setelah program aplikasi pembelajaran ini dibuat, dilanjutkan dengan kegiatan sosialisasi penggunaan program dan pendampingan penggunaan program aplikasi. Ada beberapa kegiatan yang melibatkan mitra dalam pembangunan program aplikasi ini. Kegiatan yang melibatkan mitra sebagai berikut:

1. Mitra menjadi sumber data pada tahap pengumpulan kebutuhan user terkait fasilitas yang akan dibangun di program aplikasi nantinya.

2. Ikut membantu pada proses pelatihan penggunaan program aplikasi yang sudah dibangun nantinya.

\section{HASIL DAN PEMBAHASAN}

Luaran yang dihasilkan dari kegitan Kemitraan Masyarakat ini berupa aplikasi multimedia pembelajaran interaktif menggunakan metoda colouring score (pewarnaan partitur), dimana aplikasi tersebut akan dibagi menjadi 2 macam :

1. Aplikasi multimedia versi desktop : digunakan pada saaat berlatih bersama. Peserta didik memainkan angklung dengan melihat arahan dari aplikasi yang ditampilkan melalui layar. Peserta didik menggerakkan angklung berdasarkan warna yang akan tampil di monitor yang disebut dengan colouring score. Aplikasi ini dibuat menggunakan perangkat lunak Adobe Flash CS 6.

2. Aplikasi multimedia versi mobile : digunakan ketika peserta didik belajar angklung di rumah secara mandiri. Mereka cukup menggerakkan perangkat mobile (smartphone) sebagai pengganti dari angklung. Metoda pembelajaran multimedia versi mobile ini berbentuk seperti tutorial, sehingga peserta didik dapat mempelajari angklung dari sangat dasar. Selain itu, terdapat fasilitas games sehingga peserta didik dapat bermain sambil belajar angklung dengan lebih menyenangkan. Aplikasi ini dibuat menggunakan perangkat lunak Unity3D 2017 Pro.

Sedangkan suara Angklung yang digunakan pada aplikasi ini adalah Angklung Sunda. Aplikasi ini bukanlah untuk mengganti alat musik angklung yang sebenarnya, melainkan hanya sebagai salah satu alat bantu untuk belajar angklung di rumah.Cara kerjanya adalah user cukup memilih nada mana saja yang ingin dimainkan oleh aplikasi (dengan cara me-ceklis nada tersebut) ataupun memainkan nada dengan angklung sendiri (dengan cara tidak me-ceklis nada tersebut). Contoh sederhana begini, misalnya dalam 1 buah lagu Bunda terdapat 20 nada, tetapi pemain angklung hanya 3 orang dan 3 nada saja (misalnya Do, Re dan Mi), umumnya angklung tidak dapat dimainkan dengan jumlah pemain yang sedikit. Tetapi dengan adanya aplikasi ini, user dapat bermain angklung dengan 3 nada saja karena nada lainnya dimainkan oleh komputer (aplikasi). Pemain dapat memainkan Angklung asli, maupun aplikasi Angklung versi Android yang telah dibuat pula oleh penyusun.

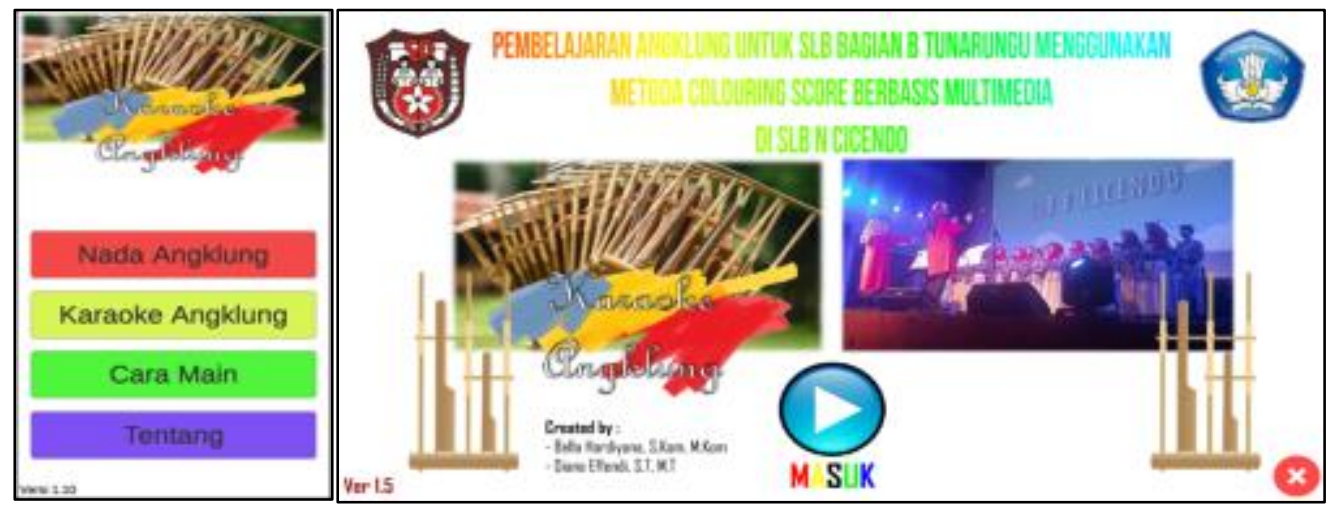

Gambar 3. Aplikasi KaraokeAngklung versi Android (kiri) dan Desktop (kanan)

Terdapat tiga lagu dalam program aplikasi pembelajaran angklung tersebut. Ketiga lagu ini mewakili lagu daerah Provinsi Jawa Barat, Lagu Populer Indonesia, dan Lagu Luar Negeri. Untuk lagu Daerah yang berasal dari Provinsi Jawa Barat adalah lagu "Peuyeum Bandung", untuk lagu Populer Indonesia dipilih agu dengan judul "Bunda", sedangkan untuk lagu yang berasal dari luar 
adalah lagu dengan judul "I Have a Dream". Contoh dari partitur yang menggunakan colouring score yang digunakan dalam program aplikasi pembelajaran angklung ini terdapat pada gambar 3 .

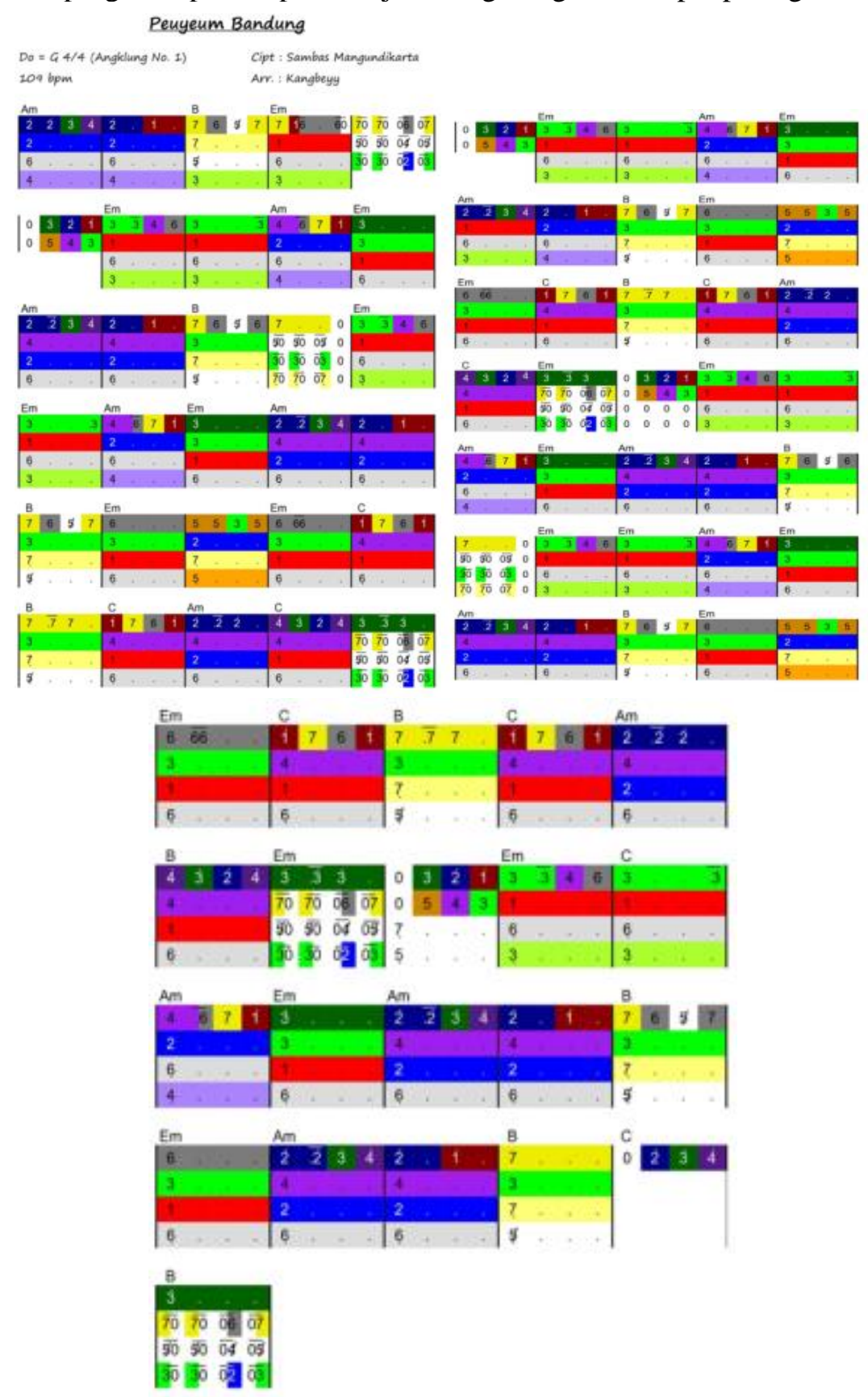

Gambar 4. Contoh Partitur Lagu Peyeumng Bandu

Pada kegiatan sosialisasi penggunaan program aplikasi tersebut diikuti sebanyak 23 siswa dengan tingkat sekolah campuran ( SD, SMP, SMA). 


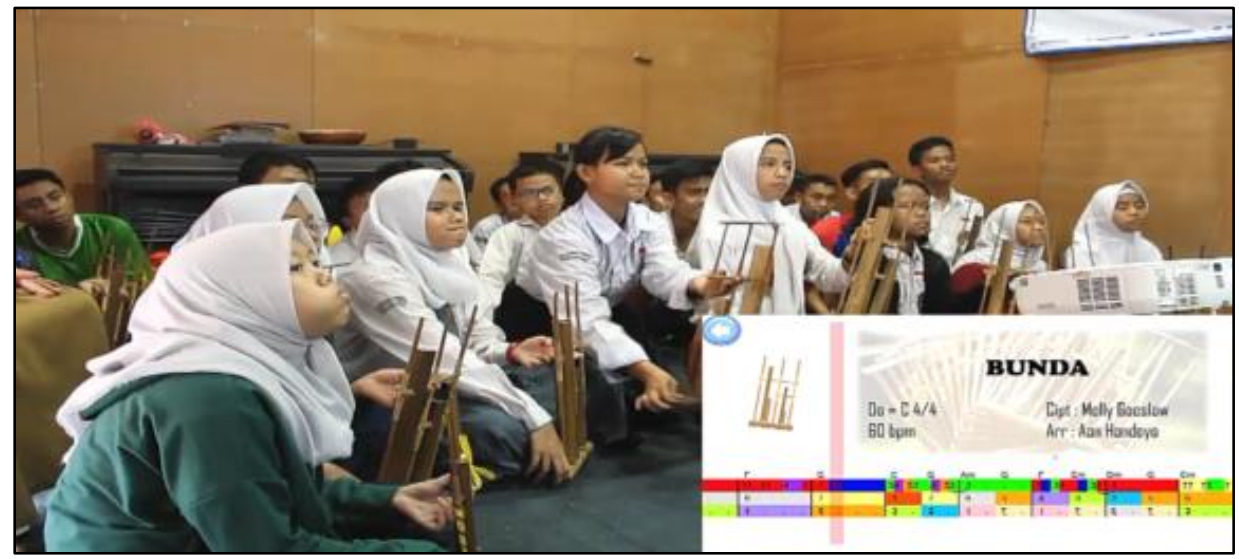

Gambar 5. Implementasi Lagu Bunda

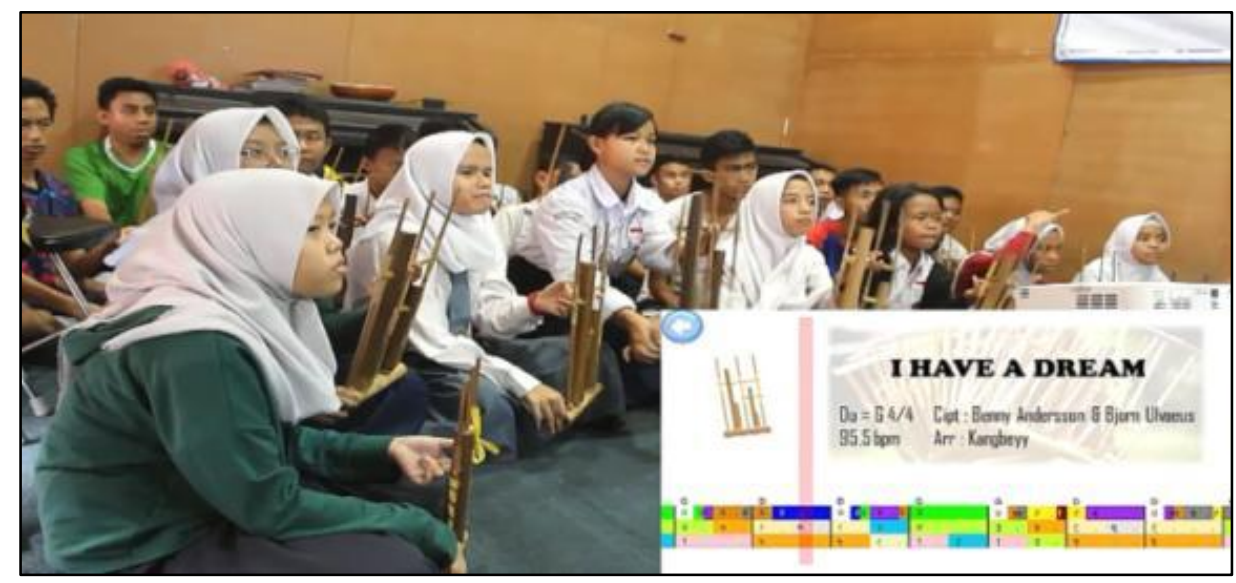

Gambar 6. Implementasi Lagu I Have a Dream

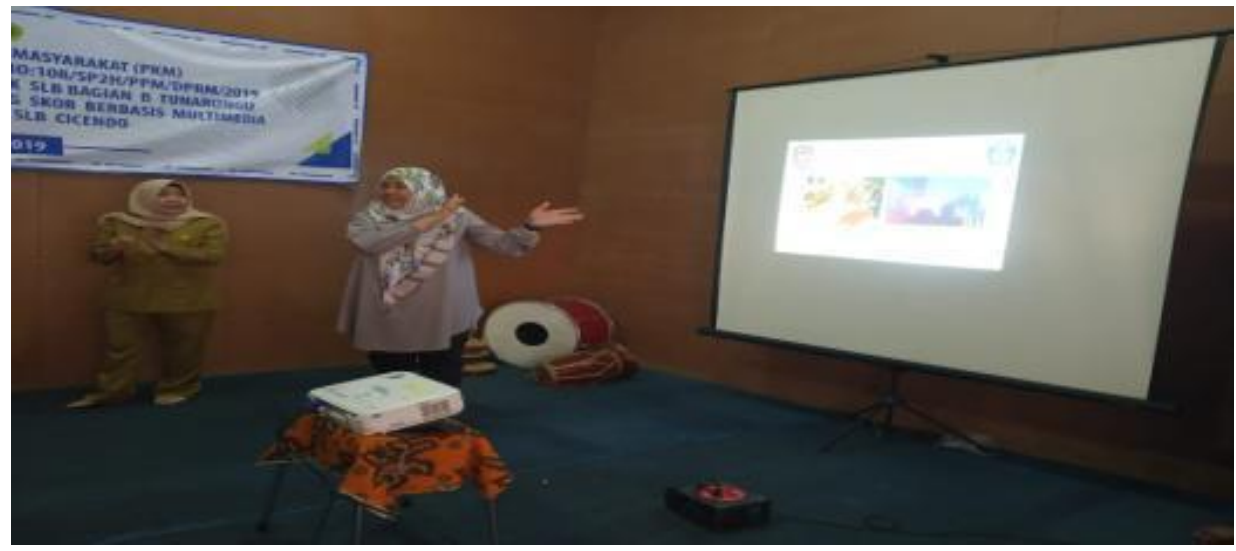

Gambar 7. Penjelasan Cara Penggunaan Program Aplikasi Pembelajaran Angklung Multimedia Berbasis Desktop 


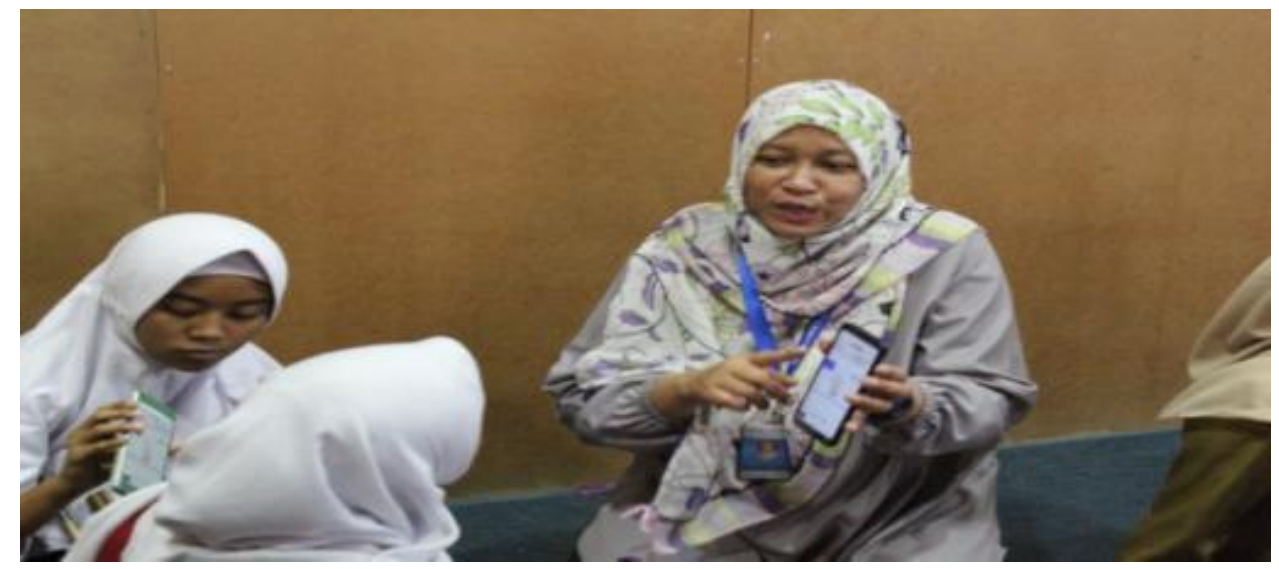

Gambar 8. Penjelasan Cara Penggunaan Program Aplikasi Pembelajaran Angklung Multimedia Berbasis Android

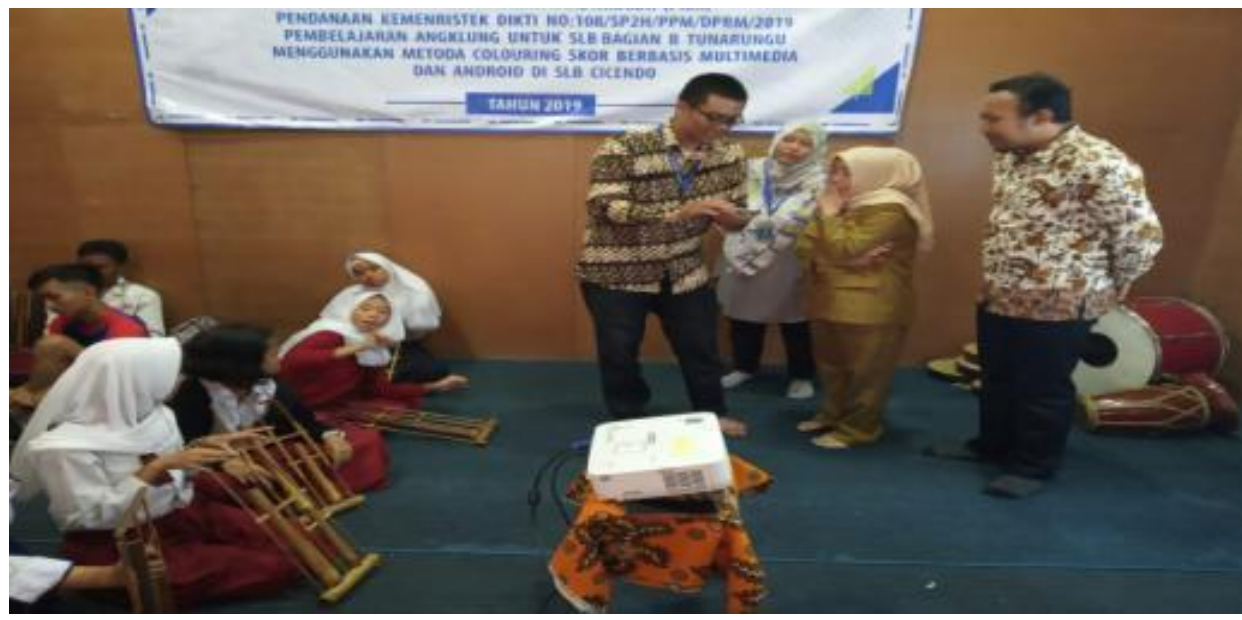

Gambar 9. Penjelasan Cara Penggunaan Program Aplikasi Pembelajaran Angklung Multimedia Berbasis Android

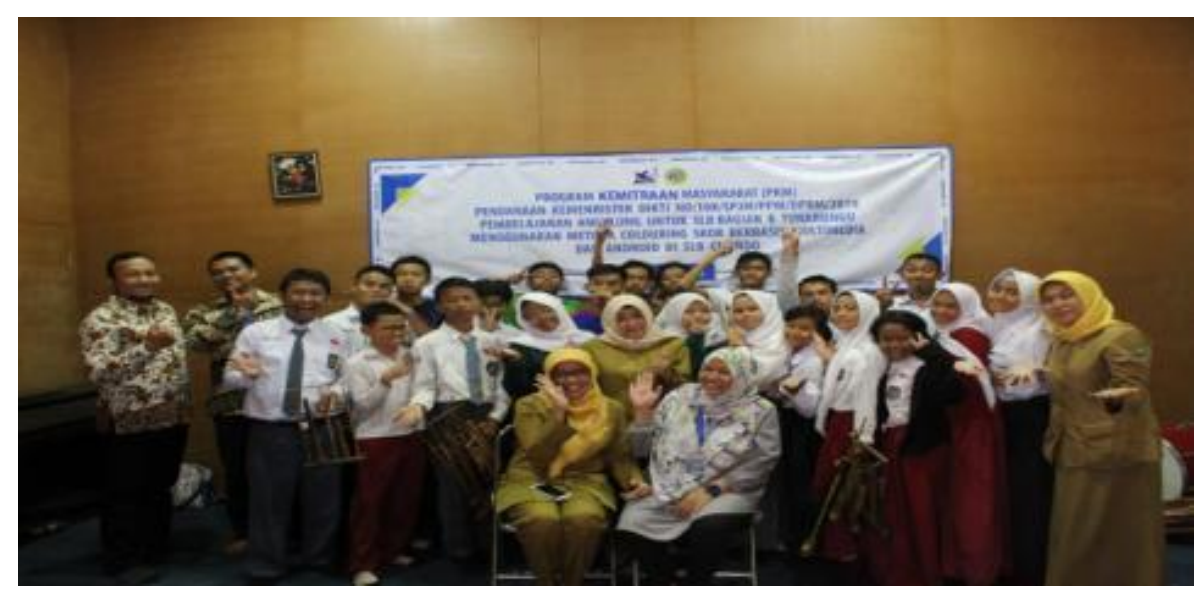

Gambar 10. Foto Bersama Peserta Sosialisasi Penggunaan Progam Aplikasi Angklung Berbasis Multimedia 


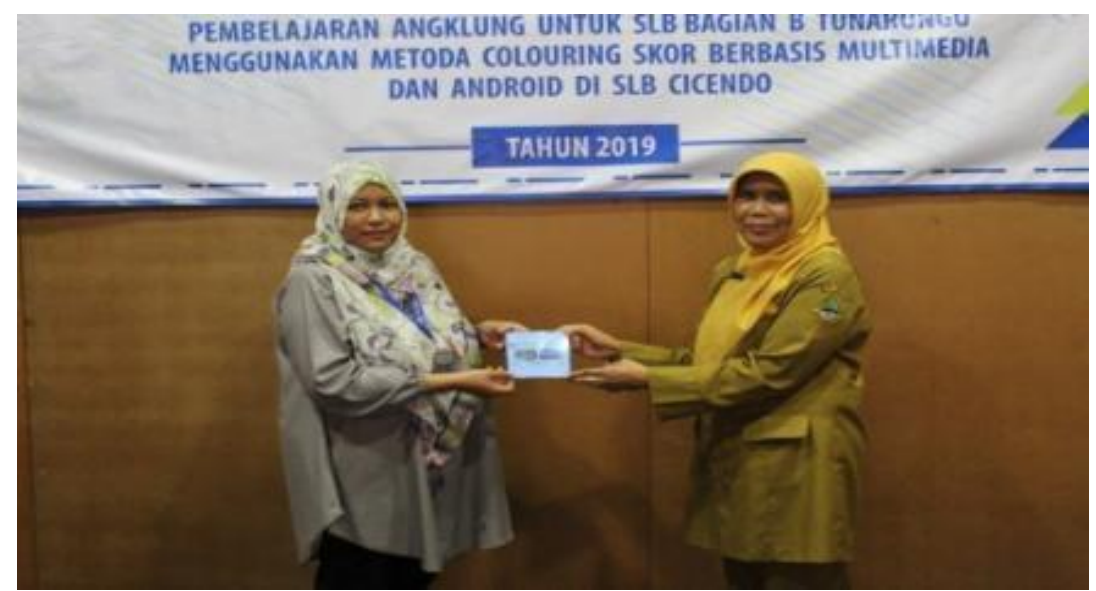

Gambar 11.Penyerahan Secara Simbolis Program Aplikasi Angklung Berbasis Multimedia Ke

Mitra

Kegiatan PKM ini mendapatkan respon dari siswa dan pembina angklung terhadap konten yang disajikan dalam program aplikasi tersebut. Siswa lebih fokus kapan harus menggerakkan angklug dengan memperhatikan perubahan warna (colouring score). Secara terperinci berikut kesimpulan dari pelaksanaan kegiatan PKM, sebagai berikut :

1. Belajar angklung bisa dimana saja dan kapan saja. Dikarenakan saat ini angklung hanya diperkenalkan sekilas di sekolah pada pelajaran kesenian yang waktunya terbatas.

2. Siswa dapat mempelajari angklung mulai dari dasar hingga dapat mengikuti pentas seni. Dikarenakan aplikasi ini berbasis tutorial learning.

3. Guru dapat lebih mudah mengajarkan notasi musik angklung lebih lengkap. Dikarenakan saat ini di sekolah mitra tidak diperkenalkan nada tabung yang sulit, seperti : fis, dis, ais, dll.

4. Siswa tidak perlu membawa angklung di rumah jika ingin bermain, cukup bermodalkan smartphone yang terinstall aplikasi multimedia ini, kemudian menggoyangkan smartphone seolah-olah itu adalah angklung.

5. Siswa dapat latihan sendiri di rumah jika ingin memainkan lagu tanpa harus menunggu di sekolah untuk bermain bersama-sama.

6. Jika siswa berlatih angklung, mereka cukup memperhatikan layar aplikasi dan menyesuaikan permainan angklung tergantung dari warna nada yang akan tampil di layar monitor. Ini memudahkan akor, karena biasanya satu akor bertanggung jawab kepada semua pemain angklung dan memberikan instruksi secara bergantian, akibatnya sering ada nada yang terlewat atau telat jika memainkan angklung secara beramai-ramai seperti pentas seni.

Keenam butir tersebut didapatkan dari hasil penyebaran kuesioner yang bertujuan untuk mengukur dampak dari program aplikasi pembelajaran angklung tersebut terhadap pemahaman siswa peserta dalam kegiatan PKM ini.

\section{KESIMPULAN}

Berdasarkan hasil pembuatan aplikasi pembelajaran musik angklung yang diimplementasi pada SLB Bagian B Tunarungu dapat disimpulkan bahwa pembelajaran musik angklung menggunakan aplikasi angklung berbasis multimedia baik melalui smartphone maupun melalui layar monitor personal computer dapat mempermudah dan membuat pemain lebih fokus terhadap bagian not yang akan harus dimainkan.

\section{SARAN}

Diharapkan dilkukan pengembangan terhadap aplikasi yang dibuat dengan menambahkan fasilitas bisa menambah lagu. Hal ini dilakukan agar lagu yang dimainkan lebih beragam jenisnya. 


\section{UCAPAN TERIMA KASIH}

Kegiatan ini merupakan bagian dari Program Kemitraan Masyarakat (PKM) yang didanai Direktorat Riset dan Pengabdian Kepada Masyarakat Direktorat Jenderal Penguatan Riset dan Pengembangan Kementrian Pendidikan danKebudayaan sesuai dengan Kontrak Nomor :108/SP2H/PPM/DPRM/2019, tanggal 08 Maret 2019.

\section{DAFTAR PUSTAKA}

[1] Indonesia, Republik. "Undang-undang No. 8 Tahun 2016 tentang penyandang disabilitas." Jakarta: Sekretariat Negara (2016).

[2] H. Inggiantowi and K. Kunci, "Sistem Tonjur untuk Menentukan Pasangan Main Angklung ke Pemain dengan Memanfaatkan MusicXML," pp. 135-141, 2011.

[3] G. Percival, Y. Wang, and G. Tzanetakis, "Effective use of multimedia for computer-assisted musical instrument tutoring," Proc. ACM Int. Multimed. Conf. Exhib., pp. 67-76, 2007.

[4] http://infobudayaindonesia.com/sejarah-dan-perkembangan-angklung/, diakses 05 Oktober 2019.

[5] https://sejarahlengkap.com/indonesia/sejarah-alat-musik-angklung/, diakses 05 Oktober 2019.

[6] Indah,Dwi. 2016. Pembelajaran Ansambel Musik Angklung Di SLB C Negeri Pembina Kalimantan Selatan, PelataranSeni Vol 1, No. 1, 11-18.

[7] Effendi, Diana.,2014. Learning Application Using Multimedia For $5^{\text {th }}$ Graders Elementary School Student about "Photosynthesis in Plants", Proceding The $1^{\text {st }}$ Sriwijaya University Learning and Education International Conference (SULE-IC), ISBN : 987-602-70378-0-9, pp.927-934.

[8] Effendi, Diana., Program Aplikasi Pembelajaran IPA Materi Sistem Peredaran Darah Manusia untuk Siswa Kelas V SDLB Bagian B (Tuna Rungu) Berbasis Multimedia, Prosiding SNETE ke-4 Jurusan Teknik ElektroUniversitasUnsyiah Banda Aceh, ISSN : 2088-9984, pp.5-10, August, 2014.

[9] Effendi, Diana, and Bella Hardiyana. "Rancangan Aplikasi Pembelajaran Angklung Untuk SLB Bagian B Tuna Rungu Berbasis Android." InfoTekJar: Jurnal Nasional Informatika dan Teknologi Jaringan 4.1 (2019).

[10] Bunawan, L., \&Yuwati. 2000. Penguasaan Bahasa Anak Tunarungu. Jakarta: Yayasan Santirama.

[11] PUTRI DIMA, A. U. L. I. Y. A. "PEMBELAJARAN MUSIK ANGKLUNG UNTUK SISWA BERKEBUTUHAN KHUSUS DI SEKOLAH LUAR BIASA NEGERI GEDANGAN SIDOARJO." Jurnal Pendidikan Sendratasik 3.1 (2015).

[12] Effendi, Diana, Bella Hardiyana, and Iyan Gustiana. "PERANCANGAN PROGRAM APLIKASI PEMBELAJARAN IPA MATERI SISTEM PERNAPASAN BERBASIS MULTIMEDIA UNTUK SISWA SDLB BAGIAN B TUNA RUNGU MENGGUNAKAN OBJECT ORIENTED APPROACH." Simetris: Jurnal Teknik Mesin, Elektro dan Ilmu Komputer 7.2 (2016): 605-618. 